British Association at Blackpool, has been further considered by Mr. W. H Smyth in the Berkeley Daily Gazette of December 5. Mr. Smyth, protesting against the mechanical conception of efficiency, urges that ultimate human efficiency should imply the liberation of man rather than the efficient control of his actions, and that the former as it gains the creative interest of the worker is likely to be the best way of achieving, though indirectly, the latter. He suggests that an act of efficiency which deals with the human element incidentally but with products as its first consideration may inevitably involve disaster to the human element. The art of efficiency in fact is misdirected if it is concerned with production as an end in itself instead of with the development of men possessing vital initiative and creative powers. Mr. Smyth sees the issue as one between human worth and human productive efficiency and one that has a vital bearing on the evolution of alternatives to war. The very value which is now attached to the work of the National Institute of Industrial Psychology in reducing labour turnover, for example, lends powerful support to Mr. Smyth's other pleas that, even in industry, efficiency should be regarded in terms of human welfare as well as of mechanical output and processes.

\section{Citizenship and the Universities}

SHould training for citizenship be an integral part of every undergraduate's curriculum? One of the smaller New England colleges, Hobart, announces a reorganization implying an affirmative answer to this question. Furthermore, the College hopes to make the bachelor's degree "represent less an aggregation of academic achievements and more an integration of intellect and of personality in the primary responsibilities of the citizen towards his community". The announcement is significant, according, as it does, with a growing tendency in the United States to emphasize the universities' obligation to the social order. In his inaugural address, published in School and Society of October 24, the president of the College explains that studies in economics, history, political science and social psychology will in future be so organized as to constitute a progressive four-year course culminating in its final year with a study of contemporary problems in American government and the means of social control. He points out that the 'orientation' courses commonly provided in colleges for the freshman year are well enough for opening the adolescent mind to a glimpse of the problems of the modern world, but are necessarily superficial and elementary compared with what is possible in the fourth year when the student has been equipped with a fairly comprehensive background of knowledge and is ready to envisage political and economic problems with interest as prospective factors in his own life. The dire need of the country for such stiffening as these reforms are calculated to provide is indicated by the statement that "Ballyhoo, the present and audible substitute for rational leadership, is well on the road to becoming the chief creator of American policy and politicians".

\section{The National Botanic Garden of South Africa}

Kinstenbosch, part of the Groot Schuur Estate at Cape Town, South Africa, bequeathed to the nation by Cecil Rhodes, was set apart in 1913 for the purposes of a National Botanic Garden. The report of the Trustees for the year 1936 (issued August 1936) shows that, in spite of its small financial resources, a very gratifying amount of botanical, educational and economic work has been done. The objects of the Gardens are "the collection, cultivation and study of the indigenous flora of South Africa; the preservation of the native vegeta. tion of the areas under control ; and the introduction to cultivation in South Africa of selected economic plants, indigenous and exotic, and their preliminary trial". During the year under review, sixteen new species have been described, and many papers have been published. Large quantities of seeds of various species have been distributed to members of the South African Botanical Society and other institutions and the trade, and more than 200 lots of succulent plants have been propagated. Perhaps the Gardens' most useful activity is shown by the announcement that $1,108 \mathrm{lb}$. of Barosma betulina has been harvested, and also $102 \mathrm{lb}$. of $B$. crenulata, $1 \mathrm{oz}$. of Dalmatian insect powder flowers, $6 \mathrm{lb}$. of sumach, and $3 \mathrm{lb}$. of tansy-products which could be brought within the channels of commerce. Trials of lawn grasses are in progress, and many additions of fresh plants have been made to all parts of the garden. The report shows that the Gardens interpret every aspect of the flora of South Africa in a marked degree. Mr. F. W. Thorns has been appointed curator of the Garden, in succession to Mr. J. W. Mathews, who has held the post of curator since the foundation of the Garden in 1913.

\section{British Empire Cancer Campaign}

Ar the sixty-first quarterly meeting of the Grand Council of the British Empire Cancer Campaign held at 12 Grosvenor Crescent on January 11, the following grants, in addition to those totalling $£ 28,995$ which were made at the annual general meeting in November, have been approved on the recommendation of the Scientific Advisory Committee of the Campaign : $£ 200$ to cover the cost of special physical investigations being carried out under the direction of Dr. F. G. Spear at the Strangeways Research Laboratory, Cambridge ; $£ 500$ for one year to Dr. H. J. Phelps, whilst carrying out experiments in connexion with Dr. Lumsden's anti-cancer serum under the supervision of Dr. Gye and Prof. McIntosh and $£ 440$ for one year to Miss C. F. Fischmann working in the Bernhard Baron Institute of Pathology at the London Hospital.

\section{Tibet Earthquake of January 7}

A GREAT earthquake was recorded in Great Britain at about 1.31 p.m. on January 7. At West Bromwich, as Mr. J. J. Shaw states, the needle of the seismograph was displaced by about $6 \frac{1}{2}$ in., or within half an inch of the amount produced by the Quetta earthquake of 1935. From the records obtained at Kew 